\title{
INFLUENCE OF IRRIGATION AND SUPPLY OF AVAIL- ABLE NITROGEN ON GROWTH AND NUTRIENT CONTENT OF SPRING WHEAT
}

\author{
Armi Kaila and Paavo Elonen \\ University of Helsinki, Department of Agricultural Chemistry
}

Received February 6, 1970

The Law of Minimum states that the amount of plant growth is regulated by the factor present in minimum amount. In southern Finland this factor is often water, particularly, when spring cereals are in question, and an improvement in the water supply during the critical period in June will increase the yield, provided no other factor will start to limit the growth. According to recent experience, on mineral soils this second factor may be nitrogen, if not more than the normal amount of fertilizer nitrogen is applied.

It is obvious that an increase in the amounts of the minimum factors will have an influence on the metabolism of the plant and on the uptake of other nutrients. Thus, effects both on the quantity and on the quality of the yield may be detected.

In order to study the dependence of growth and the nutrient content of cereals on the supply of water and nitrogen, samples of the aerial parts of spring wheat were collected at various stages of development from a field trial on irrigation and placement of nitrogen fertilizers. A part of the results of this trial have been treated from the point of view of the effect of irrigation on the uptake of nitrogen (KAILA and Elonen 1970); in the present study attention is paid to the effect of irrigation and supply of available nitrogen on the growth and the content of nutrients in the wheat plants.

\section{Experimental}

The field trial was carried out in the dry summer 1969 in cooperation with the Finnish Research Institute of Agricultural Engineering. The experimental field was in the neighbourhood of Helsinki, on silty clay soil of about $\mathrm{pH} 6$ (in $0.01 \mathrm{M} \mathrm{CaCl}_{2}$ ) with 5 per cent of organic carbon and a satisfactory content of exchangeable potassium and mavailable» phosphorus. 
As a basal dressing $800 \mathrm{~kg} / \mathrm{ha}$ of Finnish ammoniated PK-fertilizer was placed in rows at the depth of $8 \mathrm{~cm}$. Thus, $16 \mathrm{~kg} \mathrm{~N}, 59 \mathrm{~kg} \mathrm{P}$ and $100 \mathrm{~kg} \mathrm{~K}$ were applied per hectare. An additional amount of $120 \mathrm{~kg} \mathrm{~N} /$ ha was applied as a Ureaform-preparate, urea, or the Finnish ammonium nitrate limestone "Oulunsalpietari», all of them both as surface dressing or as placement. Since there was no significant difference in the effects of urea and Oulunsalpietari applied in the same way, the results obtained from these plots were combined in the present study. As surface application the effect of these fertilizers was distinctly lower than when they were placed. The response to ureaform remained rather poor, and it was equal in both manners of application. Thus, the supply of available nitrogen in this trial may be taken to represent four rates:

Very low: only the basal dressing of $16 \mathrm{~kg} \mathrm{~N} / \mathrm{ha}$.

Low: $120 \mathrm{~kg} / \mathrm{ha}$ of $\mathrm{N}$ in ureaform.

Good: $120 \mathrm{~kg} / \mathrm{ha}$ of $\mathrm{N}$ in urea or Oulunsalpietari as surface dressing.

Very good: placement of $120 \mathrm{~kg} / \mathrm{ha}$ of $\mathrm{N}$ as urea or Oulunsalpietari.

The experimental plant was "Ruso»-spring wheat, sown on May 8. It sprouted on May 20, came into ear on July 2, and was harvested on August 20.

Plant samples were collected from nonirrigated plots, and from plots irrigated with slow sprinklers on June 9 and June 17, at both times with $30 \mathrm{~mm}$ of drainage ditch water. The sampling dates were June 16, June 30, July 21, and August 18. The shoots were cut from carefully measured strips at the end of all the replicate plots. The sampling area was $0.84 \mathrm{~m}^{2}$ and $0.50 \mathrm{~m}^{2}$ in June, and $0.42 \mathrm{~m}^{2}$ in July and August. In July and August the ears were cut from the samples and analysed separately. The grain samples were taken from the winnowed material.

The samples were air-dried at room temperature, and ground in a Wiley mill. Total nitrogen was determined by the common Kjeldahl procedure. The total content of phosphorus, potassium, magnesium and calcium was measured from acid ash solution: phosphorus was determined by the ammonium vanadate molybdate method, potassium by an EEL-flame photometer, and magnesium and calcium by a Perkin-Elmer atomic absorption spectrophotometer.

The results were treated with Duncan's new multiple range test. Values of each sampling date marked by the same letter in the table do not differ at $\mathrm{P}=0.05$.

\section{Results}

The growth of spring wheat under different treatments was estimated on the basis of the amount of dry matter in the plant samples collected. These results are reported in Table 1 calculated to correspond to the amount of dry matter as $\mathrm{kg} / \mathrm{ha}$.

It is of interest to note that on June 16, there was not yet any response to the $30 \mathrm{~mm}$ of irrigation water applied one week before this sampling date. At the end of the month, or about two weeks since the application of the second $30 \mathrm{~mm}$ of irrigation water, the yields of the irrigated plots contained 750 to $1000 \mathrm{~kg} / \mathrm{ha}$ more dry matter than those of the nonirrigated plots, except when the supply of available nitrogen was very low.

The positive effect of nitrogen on the production of plant matter was apparent already on June 16. It tended to increase at the later stages of development, particularly on the irrigated plots. On these plots, the amount of dry matter produced when the nitrogen 
Table 1. Dry matter of spring wheat, $\mathrm{kg} / \mathrm{ha}$.

\begin{tabular}{|c|c|c|c|c|c|c|}
\hline & & \multirow{2}{*}{$\begin{array}{c}\text { Irrigation } \\
\mathrm{mm}\end{array}$} & \multicolumn{4}{|c|}{ Supply of available $\mathrm{N}$} \\
\hline & & & Very low & Low & Good & Very good \\
\hline \multirow[t]{2}{*}{ June 16} & Shoots & 0 & $800^{\mathrm{a}}$ & $840^{\mathrm{ab}}$ & $900^{\mathrm{ab}}$ & $1080^{\mathrm{d}}$ \\
\hline & & 30 & $850^{\mathrm{ab}}$ & $830^{\mathrm{ab}}$ & $920^{\mathrm{bc}}$ & $1020^{\mathrm{cd}}$ \\
\hline \multirow[t]{2}{*}{ June 30} & Shoots & 0 & $2550^{\mathrm{a}}$ & $2620^{\mathrm{a}}$ & $2920^{\mathrm{ab}}$ & $3250^{\text {be }}$ \\
\hline & & $30+30$ & $2660^{\mathrm{a}}$ & $3620^{c}$ & $3670^{c}$ & $4170^{\mathrm{d}}$ \\
\hline \multirow[t]{4}{*}{ July 21} & Straw & 0 & $3310^{\mathrm{a}}$ & $3690^{\mathrm{a}}$ & $4020^{\mathrm{ab}}$ & $3950^{\mathrm{ab}}$ \\
\hline & & $30+30$ & $3930^{\mathrm{ab}}$ & $4570^{\mathrm{b}}$ & $5770^{c}$ & $6300^{c}$ \\
\hline & Ears & 0 & $1210^{\mathrm{m}}$ & $1320^{\mathrm{mn}}$ & $1430^{\mathrm{n}}$ & $1370^{\mathrm{mn}}$ \\
\hline & & $30+30$ & $1320^{\mathrm{mn}}$ & $1410^{\mathrm{n}}$ & $1680^{\circ}$ & $1720^{\circ}$ \\
\hline \multirow[t]{4}{*}{ August 18} & Straw & 0 & $2210^{\mathrm{a}}$ & $2570^{\mathrm{ab}}$ & $2750^{\mathrm{abc}}$ & $3190^{\mathrm{bc}}$ \\
\hline & & $30+30$ & $3110^{\mathrm{bc}}$ & $3550^{c}$ & $4760^{\mathrm{d}}$ & $5380^{\mathrm{d}}$ \\
\hline & Ears & 0 & $2830^{\mathrm{m}}$ & $3360^{\mathrm{mn}}$ & $3670^{\mathrm{mn}}$ & $4050^{\mathrm{n}}$ \\
\hline & & $30+30$ & $4070^{\mathrm{n}}$ & $4180^{\mathrm{n}}$ & $5590^{\circ}$ & $6120^{\circ}$ \\
\hline
\end{tabular}

supply was very good was on June 16, June 30, July 21, and August 18 about 20, 36, 53, and 61 per cent higher, respectively, than the corresponding yields on the plots with very low nitrogen supply.

The positive effect of irrigation appears to be markedly higher with good or very good supply of available nitrogen than with low or very low supply. On July 21, e.g., the increase in the total dry matter yield by irrigation was less than 20 per cent when the supply of nitrogen was very low or low, but 37 per cent when the nitrogen supply was good, and more than 50 per cent when it was very good.

On the basis of the results of August 18, the response to the placement of $120 \mathrm{~kg} / \mathrm{ha}$ of soluble fertilizer nitrogen was $2200 \mathrm{~kg} / \mathrm{ha}$ of dry matter, the effect of irrigation alone corresponded to $2140 \mathrm{~kg} / \mathrm{ha}$, and the combined effect of both these treatments resulted in an increase of $6460 \mathrm{~kg} / \mathrm{ha}$ in the dry matter production. The positive interaction of water and nitrogen supply is obvious.

The nitrogen content of the plant samples (Table 2) gives a slightly different picture. The nitrogen percentage tended, of course, to rise with the improvement in the supply of available nitrogen, but the effect of irrigation was more complicated on the nitrogen content than on the dry matter yield. In June, the samples collected from the irrigated plots contained, in most cases, significantly more nitrogen than the corresponding samples of nonirrigated plots. In the July samples, there is no more any significant difference between the nitrogen content of the corresponding samples. In the ears, there is some tendency to lower nitrogen content in the irrigated samples, and this is statistically significant in the samples of August 18, except when the nitrogen supply was very low. In the straw samples this difference is significant only with very good nitrogen supply. 
Table 2. $\mathrm{N}$ in spring wheat, per cent of dry matter.

\begin{tabular}{|c|c|c|c|c|c|c|}
\hline & & \multirow{2}{*}{$\begin{array}{c}\text { Irrigation } \\
\text { mm }\end{array}$} & \multicolumn{4}{|c|}{ Supply of available $\mathrm{N}$} \\
\hline & & & Very low & Low & Good & Very good \\
\hline \multirow[t]{2}{*}{ June 16} & Shoots & 0 & $2.71^{\mathrm{a}}$ & $2.86^{\mathrm{a}}$ & $3.21^{\mathrm{b}}$ & $3.85^{\mathrm{c}}$ \\
\hline & & 30 & $2.85^{\mathrm{a}}$ & $3.30^{\mathrm{b}}$ & $3.95^{\mathrm{c}}$ & $4.30^{\mathrm{d}}$ \\
\hline \multirow[t]{2}{*}{ June 30} & Shoots & 0 & $1.53^{\mathrm{a}}$ & $1.67^{\mathrm{b}}$ & $1.86^{\mathrm{c}}$ & $2.08^{\mathrm{d}}$ \\
\hline & & $30+30$ & $1.68^{\mathrm{b}}$ & $1.85^{\mathrm{c}}$ & $2.33^{e}$ & $2.50^{f}$ \\
\hline \multirow[t]{4}{*}{ July 21} & Straw & 0 & $0.85^{\mathrm{a}}$ & $0.99^{\mathrm{b}}$ & $1.32^{\mathrm{c}}$ & $1.56^{\mathrm{e}}$ \\
\hline & & $30+30$ & $0.95^{\mathrm{ab}}$ & $0.92^{\mathrm{ab}}$ & $1.38^{\mathrm{cd}}$ & $1.47 \mathrm{de}$ \\
\hline & Ears & 0 & $2.20^{\mathrm{m}}$ & $2.34^{\mathrm{mn}}$ & $2.50^{\text {no }}$ & $2.58^{\circ}$ \\
\hline & & $30+30$ & $2.21^{\mathrm{m}}$ & $2.21^{\mathrm{m}}$ & $2.38^{\mathrm{mn}}$ & $2.46^{\mathrm{no}}$ \\
\hline \multirow[t]{4}{*}{ August 18} & Straw & 0 & $0.38^{\mathrm{a}}$ & $0.43^{\mathrm{a}}$ & $0.52^{\mathrm{b}}$ & $0.69^{\mathrm{c}}$ \\
\hline & & $30+30$ & $0.35^{\mathrm{a}}$ & $0.36^{\mathrm{a}}$ & $0.55^{\mathrm{b}}$ & $0.58^{\mathrm{b}}$ \\
\hline & Ears & 0 & $1.78^{\mathrm{m}}$ & $2.00^{\mathrm{n}}$ & $2.47 \mathrm{p}$ & $2.72^{\mathrm{q}}$ \\
\hline & & $30+30$ & $1.79^{\mathrm{m}}$ & $1.79^{\mathrm{m}}$ & $2.27^{\circ}$ & $2.37 \mathrm{op}$ \\
\hline
\end{tabular}

The phosphorus content of the plant samples is reported in Table 3. In the June samples, irrigation significantly increased the phosphorus content, provided the nitrogen supply was not very low. A similar tendency is also found in the straw samples of July 21 .

Table 3. $\mathrm{P} \mathrm{mg} / \mathrm{g}$ of dry matter.

\begin{tabular}{|c|c|c|c|c|c|c|}
\hline & & \multirow{2}{*}{$\begin{array}{c}\text { Irrigation } \\
\mathrm{mm}\end{array}$} & \multicolumn{4}{|c|}{ Supply of available $\mathrm{N}$} \\
\hline & & & Very low & Low & Good & Very good \\
\hline \multirow[t]{2}{*}{ June 16} & Shoots & 0 & $3.32^{\mathrm{b}}$ & $3.17 \mathrm{a}$ & $3.14^{\mathrm{a}}$ & $3.06^{\mathrm{a}}$ \\
\hline & & 30 & $3.05^{\mathrm{a}}$ & $3.62^{\mathrm{c}}$ & $3.82^{\mathrm{d}}$ & $3.50^{\mathrm{c}}$ \\
\hline \multirow[t]{2}{*}{ June 30} & Shoots & 0 & $2.03^{b}$ & $1.87^{\mathrm{ab}}$ & $1.84^{\mathrm{ab}}$ & $1.73^{\mathrm{a}}$ \\
\hline & & $30+30$ & $2.02^{\mathrm{b}}$ & $2.43^{\mathrm{c}}$ & $2.38^{\mathrm{c}}$ & $2.38^{\mathrm{c}}$ \\
\hline \multirow[t]{4}{*}{ July 21} & Straw & 0 & $1.32^{\mathrm{ab}}$ & $1.28^{\mathrm{a}}$ & $1.42^{\mathrm{abc}}$ & $1.50^{\text {bod }}$ \\
\hline & & $30+30$ & $1.33^{\mathrm{ab}}$ & $1.44^{\mathrm{abcd}}$ & $1.59^{\mathrm{cd}}$ & $1.62^{\mathrm{d}}$ \\
\hline & Ears & 0 & $3.64^{\mathrm{n}}$ & $3.64^{\mathrm{n}}$ & $3.61^{\mathrm{mn}}$ & $3.53^{\mathrm{mn}}$ \\
\hline & & $30+30$ & $3.53^{\mathrm{mn}}$ & $3.64^{\mathrm{n}}$ & $3.50^{\mathrm{mn}}$ & $3.45^{\mathrm{m}}$ \\
\hline \multirow[t]{4}{*}{ August 18} & Straw & 0 & $0.51^{\mathrm{a}}$ & $0.49^{\mathrm{a}}$ & $0.48^{\mathrm{a}}$ & $0.52^{\mathrm{a}}$ \\
\hline & & $30+30$ & $0.41^{\mathrm{a}}$ & $0.41^{\mathrm{a}}$ & $0.42^{\mathrm{a}}$ & $0.43^{\mathrm{a}}$ \\
\hline & Ears & 0 & $3.54^{\circ}$ & $3.42^{\circ}$ & $3.35^{\text {no }}$ & $3.34^{\text {no }}$ \\
\hline & & $30+30$ & $3.40^{\mathrm{no}}$ & $3.17 \mathrm{mn}$ & $3.05^{\mathrm{m}}$ & $2.94^{\mathrm{m}}$ \\
\hline
\end{tabular}


Table $4 . \mathrm{K} \mathrm{mg} / \mathrm{g}$ of dry matter.

\begin{tabular}{|c|c|c|c|c|c|c|}
\hline & & \multirow{2}{*}{$\begin{array}{c}\text { Irrigation } \\
\mathrm{mm}\end{array}$} & \multicolumn{4}{|c|}{ Supply of available $\mathrm{N}$} \\
\hline & & & Very low & Low & Good & Very good \\
\hline \multirow{2}{*}{ June 16} & Shoots & 0 & $36.7^{\mathrm{a}}$ & $38.1^{\mathrm{ab}}$ & $40.3^{\mathrm{bc}}$ & $44.2^{\mathrm{d}}$ \\
\hline & & 30 & $38.4^{\mathrm{ab}}$ & $41.8^{c}$ & $45.6^{\mathrm{d}}$ & $45.7^{d}$ \\
\hline \multirow[t]{2}{*}{ June 30} & Shoots & 0 & $20.6^{\mathrm{a}}$ & $21.9^{\mathrm{ab}}$ & $22.5^{\mathrm{b}}$ & $25.2^{\mathrm{c}}$ \\
\hline & & $30+30$ & $22.6^{\mathrm{b}}$ & $26.3^{c}$ & $29.6^{\mathrm{d}}$ & $31.5^{e}$ \\
\hline \multirow[t]{4}{*}{ July 21} & Straw & $\mathbf{0}$ & $15.0^{\mathrm{b}}$ & $16.0^{\mathrm{c}}$ & $18.9^{e}$ & $19.9^{f}$ \\
\hline & & $30+30$ & $13.3^{\mathrm{a}}$ & $14.0^{\mathrm{a}}$ & $15.7 \mathrm{bc}$ & $17.3^{\mathrm{d}}$ \\
\hline & Ears & 0 & $6.3^{\mathrm{mn}}$ & $6.0^{\mathrm{m}}$ & $6.2^{\mathrm{mn}}$ & $6.3^{\mathrm{mn}}$ \\
\hline & & $30+30$ & $6.5^{\mathrm{n}}$ & $7.2^{\circ}$ & $7.0^{\circ}$ & $7.2^{\circ}$ \\
\hline \multirow[t]{4}{*}{ August 18} & Straw & 0 & $16.0^{\mathrm{a}}$ & $18.2^{\mathrm{bc}}$ & $19.6^{\mathrm{c}}$ & $21.2^{\mathrm{d}}$ \\
\hline & & $30+30$ & $16.8^{\mathrm{ab}}$ & $18.8^{\mathrm{c}}$ & $22.6^{\mathrm{d}}$ & $22.7 \mathrm{~d}$ \\
\hline & Ears & 0 & $4.5^{\mathrm{n}}$ & $4.4^{\mathrm{mn}}$ & $3.9^{\mathrm{m}}$ & $4.0^{\mathrm{m}}$ \\
\hline & & $30+30$ & $4.4^{\mathrm{mn}}$ & $4.6^{\mathrm{n}}$ & $3.9^{\mathrm{m}}$ & $3.9^{\mathrm{m}}$ \\
\hline
\end{tabular}

This means that irrigation markedly improved the uptake of phosphorus by plants, since also the dry matter yields were increased. This increase in the accumulation of phosphorus in the shoots corresponded to 60 to 80 per cent in the samples of June 30. Later, the higher production of dry matter on the irrigated plots diluted the phosphorus concentration, but this is statistically significant only in the ears of August 18.

The effect of nitrogen on the phosphorus content of the plant samples was less distinct than that of irrigation. Though there usually was a tendency to a slightly lower phosphorus content in the higher dry matter yields produced by the better supply of nitrogen, also some exceptions may be found.

The potassium content (Table 4) appears to be more closely connected with the supply of nitrogen than the phosphorus content was. The potassium content of shoots and straw increased with improving nitrogen supply both in the irrigated and nonirrigated samples. In the potassium content of the ears, the differences between the nitrogen treatments were low, and there was in August a distinct tendency to a lower content of potassium in the higher dry matter yields produced by better nitrogen supply.

Irrigation increased markedly the potassium content of the samples in June. In July it decreased the potassium content of straw, but increased that of ears. In August, there is again a distinct tendency to a higher potassium content in the straw samples of the irrigated plots, but no difference between the corresponding samples of ears is detectable.

When the magnesium content of the plants are examined, the question arises, whether attention must be paid to the dolomitic magnesium (3\%) in Oulunsalpietari. In this trial only in the irrigated samples of June 16 there was a somewhat higher magnesium content in the shoots from the plots treated with Oulunsalpietari as compared with the 
corresponding samples treated with urea. In no other cases any significant difference was detected between the effects of these two fertilizers on the magnesium content of the samples, not even any average tendency to a higher magnesium content with Oulunsalpietari.

Both irrigation and a better supply of nitrogen increased the magnesium content of the shoots in June (Table 5). The positive effect of nitrogen is apparent even in the magnesium content of the straw samples in July and August. The higher yields of irrigated plots resulted in July and August in somewhat lower content of magnesium in the ears.

Table 5. $\mathrm{Mg} \mathrm{mg} / \mathrm{g}$ of dry matter.

\begin{tabular}{|c|c|c|c|c|c|c|}
\hline & & \multirow{2}{*}{$\begin{array}{c}\text { Irrigation } \\
\text { mm }\end{array}$} & \multicolumn{4}{|c|}{ Supply of available $\mathrm{N}$} \\
\hline & & & Very low & Low & Good & Very good \\
\hline \multirow[t]{2}{*}{ June 16} & Shoots & 0 & $1.50^{\mathrm{a}}$ & $1.51^{\mathrm{a}}$ & $1.57^{\mathrm{a}}$ & $1.69^{\mathrm{b}}$ \\
\hline & & 30 & $1.55^{\mathrm{a}}$ & $1.58^{\mathrm{a}}$ & $1.72^{b}$ & $1.86^{\mathrm{c}}$ \\
\hline \multirow[t]{2}{*}{ June 30} & Shoots & 0 & $1.19^{\mathrm{a}}$ & $1.17^{\mathrm{a}}$ & $1.21^{\mathrm{a}}$ & $1.33^{\mathrm{b}}$ \\
\hline & & $30+30$ & $1.19^{\mathrm{a}}$ & $1.23^{\mathrm{a}}$ & $1.41^{b c}$ & $1.49^{\mathrm{c}}$ \\
\hline \multirow[t]{4}{*}{ July 21} & Straw & 0 & $0.86^{b}$ & $0.89^{b}$ & $0.95^{\mathrm{c}}$ & $1.07^{\mathrm{d}}$ \\
\hline & & $30+30$ & $0.84^{b}$ & $0.77^{\mathrm{a}}$ & $1.03^{\mathrm{d}}$ & $1.04^{\mathrm{d}}$ \\
\hline & Ears & 0 & $1.32^{\mathrm{no}}$ & $1.33^{\mathrm{no}}$ & $1.38^{\circ}$ & $1.34^{\mathrm{no}}$ \\
\hline & & $30+30$ & $1.34^{\text {no }}$ & $1.21^{\mathrm{m}}$ & $1.28^{\mathrm{mn}}$ & $1.27 \mathrm{mn}$ \\
\hline \multirow[t]{4}{*}{ August 18} & Straw & 0 & $0.88^{b c}$ & $0.84^{b}$ & $0.95^{\mathrm{cd}}$ & $1.01^{\mathrm{d}}$ \\
\hline & & $30+30$ & $0.81^{b}$ & $0.70^{\mathrm{a}}$ & $0.91^{b c}$ & $1.02^{\mathrm{d}}$ \\
\hline & Ears & 0 & $1.17^{\mathrm{n}}$ & $1.15^{\mathrm{n}}$ & $1.21^{\mathrm{n}}$ & $1.21^{\mathrm{n}}$ \\
\hline & & $30+30$ & $1.14^{\mathrm{n}}$ & $1.00^{\mathrm{m}}$ & $1.07^{\mathrm{m}}$ & $1.06^{\mathrm{m}}$ \\
\hline
\end{tabular}

Data in Table 6 show that the effect of irrigation and nitrogen supply on the calcium content of the plant samples is similar to their influence on the magnesium content. Only, in July, both straw and ears tended to be richer in calcium on the irrigated plots.

The grain yields were winnowed, and thus the material analysed represents pure mature grains. Data in Table 7 indicate that dry matter yields were significantly increased by irrigation at all levels of available nitrogen supply. This increase in the dry matter yield was more than $1400 \mathrm{~kg} / \mathrm{ha}$ when the supply of nitrogen was good or very good, but only about $600 \mathrm{~kg} / \mathrm{ha}$, when it was low or very low. The response to nitrogen was marked: the good supply of available nitrogen produced about 60 per cent more grains without irrigation, and about 80 per cent more with irrigation than did the very low supply of nitrogen. Yet, even the latter yields were by no means low.

Irrigation decreased the nitrogen content of grains by 7 to 15 per cent. Since the nitrogen content of grains from the nonirrigated plots was high or very high, this drop is not serious. 
Table 6. Ca mg/g of dry matter.

\begin{tabular}{|c|c|c|c|c|c|c|}
\hline \multirow[t]{2}{*}{$=$} & & \multirow{2}{*}{$\begin{array}{c}\text { Irrigation } \\
\mathrm{mm}\end{array}$} & \multicolumn{4}{|c|}{ Supply of available $\mathrm{N}$} \\
\hline & & & Very low & Low & Good & Very good \\
\hline \multirow[t]{2}{*}{ June 16} & Shoots & 0 & $4.02^{\mathrm{a}}$ & $4.15^{\mathrm{ab}}$ & $4.69^{c}$ & $4.70^{c}$ \\
\hline & & 30 & $4.47 \mathrm{bc}$ & $4.86^{c}$ & $5.28^{\mathrm{d}}$ & $5.36^{\mathrm{d}}$ \\
\hline \multirow[t]{2}{*}{ June 30} & Shoots & 0 & $1.94^{\mathrm{a}}$ & $1.90^{\mathrm{a}}$ & $2.09^{\mathrm{a}}$ & $2.34^{\mathrm{b}}$ \\
\hline & & $30+30$ & $2.04^{\mathrm{a}}$ & $2.42^{\mathrm{b}}$ & $2.87^{c}$ & $2.79^{c}$ \\
\hline \multirow[t]{4}{*}{ July 21} & Straw & 0 & $1.54^{\mathrm{a}}$ & $1.56^{\mathrm{a}}$ & $1.73^{b}$ & $1.92^{\mathrm{c}}$ \\
\hline & & $30+30$ & $1.50^{\mathrm{a}}$ & $1.64^{\mathrm{ab}}$ & $2.08^{d}$ & $2.02^{\mathrm{cd}}$ \\
\hline & Ears & 0 & $0.81^{\mathrm{m}}$ & $0.83^{\mathrm{mn}}$ & $0.86^{\mathrm{mn}}$ & $0.91^{\mathrm{mno}}$ \\
\hline & & $30+30$ & $0.89^{\mathrm{mno}}$ & $0.90^{\mathrm{mno}}$ & $0.95^{\text {no }}$ & $0.99^{\circ}$ \\
\hline \multirow[t]{4}{*}{ August 18} & Straw & 0 & $1.99^{\mathrm{a}}$ & $1.95^{\mathrm{a}}$ & $2.20^{\mathrm{b}}$ & $2.23^{\mathrm{b}}$ \\
\hline & & $30+30$ & $1.81^{\mathrm{a}}$ & $1.95^{\mathrm{a}}$ & $2.37^{b}$ & $2.36^{\mathrm{b}}$ \\
\hline & Ears & 0 & $0.76^{n}$ & $0.73^{\mathrm{mn}}$ & $0.77^{\mathrm{n}}$ & $0.75^{n}$ \\
\hline & & $30+30$ & $0.71^{\mathrm{mn}}$ & $0.72^{\mathrm{mn}}$ & $0.67^{\mathrm{m}}$ & $0.66^{\mathrm{m}}$ \\
\hline
\end{tabular}

Table 7. Grain yield.

\begin{tabular}{|c|c|c|c|c|c|}
\hline & \multirow{2}{*}{$\begin{array}{c}\text { Irrigation } \\
\mathrm{mm}\end{array}$} & \multicolumn{4}{|c|}{ Supply of available $\mathrm{N}$} \\
\hline & & Very low & Low & Good & Very good \\
\hline \multirow[t]{2}{*}{ Dry matter $\mathrm{kg} / \mathrm{ha}$} & 0 & $1920^{\mathrm{a}}$ & $2080^{a}$ & $2690^{b}$ & $3060^{c}$ \\
\hline & $30+30$ & $2510^{b}$ & $2700^{b}$ & $4180^{d}$ & $4480^{d}$ \\
\hline \multirow[t]{2}{*}{$\mathrm{N} \mathrm{mg/g}$} & 0 & $23.0^{\mathrm{b}}$ & $24.1^{b}$ & $30.2^{\mathrm{d}}$ & $30.9^{d}$ \\
\hline & $30+30$ & $21.3^{\mathrm{a}}$ & $20.8^{a}$ & $26.0^{\mathrm{c}}$ & $26.1^{\mathrm{c}}$ \\
\hline \multirow[t]{2}{*}{$\mathrm{P} \mathrm{mg} / \mathrm{g}$} & 0 & $4.32^{b}$ & $4.20^{\mathrm{b}}$ & $4.19^{b}$ & $4.15^{b}$ \\
\hline & $30+30$ & $4.25^{\mathrm{b}}$ & $4.18^{b}$ & $3.89^{\mathrm{a}}$ & $3.83^{\mathrm{a}}$ \\
\hline \multirow[t]{2}{*}{$\mathrm{K} \mathrm{mg} / \mathrm{g}$} & 0 & $4.49^{c}$ & $4.37 \mathrm{bc}$ & $4.17^{\mathrm{ab}}$ & $4.09^{\mathrm{a}}$ \\
\hline & $30+30$ & $4.54^{\mathrm{c}}$ & $4.53^{c}$ & $4.12^{\mathrm{a}}$ & $3.98^{\mathrm{a}}$ \\
\hline \multirow[t]{2}{*}{$\mathrm{Mg} \mathrm{mg} / \mathrm{g}$} & 0 & $1.35^{\mathrm{bc}}$ & $1.36^{\mathrm{bcd}}$ & $1.42^{\mathrm{d}}$ & $1.39^{\mathrm{cd}}$ \\
\hline & $30+30$ & $1.33^{\mathrm{abc}}$ & $1.28^{\mathrm{a}}$ & $1.31 \mathrm{ab}$ & $1.28^{\mathrm{a}}$ \\
\hline \multirow[t]{2}{*}{$\mathrm{Ca} \mathrm{mg} / \mathrm{g}$} & 0 & $0.63^{\mathrm{a}}$ & $0.63^{\mathrm{a}}$ & $0.62^{\mathrm{a}}$ & $0.62^{\mathrm{a}}$ \\
\hline & $30+30$ & $0.69^{b}$ & $0.69^{b}$ & $0.64^{\mathrm{a}}$ & $0.62^{\mathrm{a}}$ \\
\hline
\end{tabular}

Means of dry matter yield and means of the content of respective nutrients followed by the same letter do not differ at $\mathrm{P}=0.05$. 
The grains were not poor in phosphorus, and only with good or very good supply of nitrogen irrigation decreased this content significantly. The potassium content of grain dry matter seems to decrease with improving supply of nitrogen, but irrigation had no significant effect. The magnesium content, on the other hand, did not markedly depend on the nitrogen supply, and it was distinctly decreased by irrigation, except when the nitrogen supply was very low. The calcium content was slightly increased by irrigation when the nitrogen supply was low or very low, but no difference was found when the supply was good or very good.

It is alluring to use the results obtained from the samples collected on August 18, or two days before harvest, to estimate the amount of these nutrients in the mature wheat crop. These figures are recorded in Table 8. The amounts of nutrients in the irrigated crops are markedly higher than those in the corresponding nonirrigated ones, particularly, when the nitrogen supply was good or very good. Also the increase in the yields due to better supply of nitrogen resulted in higher uptake of potassium, phosphorus, magnesium, and calcium by the crop.

Table 8. Nutrients in ears and straw two days before harvest.

\begin{tabular}{|c|c|c|c|c|c|}
\hline \multirow{2}{*}{$\begin{array}{l}\text { Nutrient } \\
\mathrm{kg} / \mathrm{ha}\end{array}$} & \multirow{2}{*}{$\begin{array}{c}\text { Irrigation } \\
\mathrm{mm}\end{array}$} & \multicolumn{4}{|c|}{ Supply of available $\mathrm{N}$} \\
\hline & & Very low & Low & Good & Very good \\
\hline \multirow[t]{2}{*}{$\mathbf{N}$} & 0 & $59^{a}$ & $78^{\mathrm{ab}}$ & $102^{\mathrm{bc}}$ & $130^{\mathrm{cd}}$ \\
\hline & $30+30$ & $84^{\text {ab }}$ & $87^{a b}$ & $151^{\text {de }}$ & $175^{e}$ \\
\hline \multirow[t]{2}{*}{ K } & 0 & $48^{\mathrm{a}}$ & $61^{\mathrm{ab}}$ & 67 abc & $83^{c}$ \\
\hline & $30+30$ & $70^{\mathrm{bc}}$ & $86^{c}$ & $129 \mathrm{~d}$ & $145^{\mathrm{d}}$ \\
\hline \multirow[t]{2}{*}{$\mathbf{P}$} & 0 & $11^{\mathrm{a}}$ & $13^{a}$ & $13^{a}$ & $15^{\mathrm{ab}}$ \\
\hline & $30+30$ & $15^{\mathrm{ab}}$ & $15^{\mathrm{ab}}$ & $19^{b c}$ & $20^{c}$ \\
\hline \multirow[t]{2}{*}{$\mathrm{Mg}$} & 0 & $5^{a}$ & $6^{\mathrm{ab}}$ & $7^{a b}$ & $8^{b c}$ \\
\hline & $30+30$ & $7 \mathrm{ab}$ & $7 \mathrm{ab}$ & $10^{\mathrm{cd}}$ & $12^{\mathrm{d}}$ \\
\hline \multirow[t]{2}{*}{$\mathrm{Ca}$} & 0 & $7^{a}$ & $7^{a}$ & $9^{a b}$ & $10^{\mathrm{b}}$ \\
\hline & $30+30$ & $8^{\mathrm{ab}}$ & $10^{\mathrm{b}}$ & $15^{\mathrm{c}}$ & $17 \mathrm{c}$ \\
\hline
\end{tabular}

Means of each nutrient followed by the same letter do not differ at $\mathrm{P}=0.05$.

When the nitrogen supply was good or very good, irrigation increased the nutrients in the crop by almost $50 \mathrm{~kg} / \mathrm{ha}$ of nitrogen, about $60 \mathrm{~kg} / \mathrm{ha}$ of potassium, 5 to $6 \mathrm{~kg} / \mathrm{ha}$ of phosphorus, 3 to $4 \mathrm{~kg} / \mathrm{ha}$ of magnesium, and 6 to $7 \mathrm{~kg} / \mathrm{ha}$ of calcium. The highest yield, produced by irrigation and very good supply of nitrogen, contained three times as much nitrogen and potassium, about 2.4 times as much magnesium and calcium, and almost 
twice as much phosphorus as the lowest yield with very low supply of available nitrogen and without irrigation.

\section{Discussion}

In this field trial in a dry summer the yield of spring wheat was markedly increased by the application of $60 \mathrm{~mm}$ irrigation water during the critical period before the development of ears. In order to get the best results, also $136 \mathrm{~kg} / \mathrm{ha}$ of soluble fertilizer nitrogen placed in rows was necessary.

The high production of grain by irrigation and nitrogen dressing was possible, partly, because both treatments, particularly the irrigation, allowed a more intensive uptake of essential nutrients during the most vigorous vegetative growth. Thus the shoots in June had a high content of at least nitrogen, phosphorus, potassium, magnesium, and calcium, all of them necessary for the photosynthesis and building up of plant material.

It is easy to understand that in a dry soil the nutrients of fertilizers are not readily dissolved. Also, the availability of soil sources may be decreased. Thus, moistening of the soil is likely to enhance the uptake of nutrients by roots. On the other hand, it has been found that irrigation is likely to produce a larger root system (KÄHÄRI and ELONEN 1969), and even in this way it may improve the uptake of nutrients from soil and fertilizers.

It is possible that most of the nitrogen was nitrified before the plants absorbed it. Therefore, the effect of nitrogen in increasing the potassium, magnesium and calcium content of the aerial vegetative parts of wheat may be partly connected with a higher uptake of cations to balance the more intensive absorption of nitrate anion. The phosphorus content, the uptake of phosphate anion, was to a far lower degree affected by the nitrogen supply. Probably, also the root system tended to be more vigorous, and the plant metabolism in general intensified, when the nitrogen content of the cells was not a minimum factor.

The present results emphasize the importance of providing also other nutrients in sufficient amounts, when the usual minimum factors, water and nitrogen, are no more limiting the growth.

In this trial a good yield was produced without irrigation and with a heavy treatment with soluble nitrogen applied as surface dressing which corresponds to the common practice in Finland. The top yield produced by irrigation and placement of the nitrogen fertilizer contained, according to the plant samples collected two days before harvest, more than twice as much potassium as the mormal»yield. The increase in the phosphorus requirement was about 50 per cent of the phosphorus content in the "normal» yield. The uptake of magnesium and calcium were increased 70 and 90 per cent, respectively. The top yield contained more nitrogen and potassium than was applied in the fertilizers. In this soil rich in organic matter and clay, the deficit could be made up by the soil sources, particularly, since irrigation was likely to enhance their mobilization.

There is no doubt that the improvement in the efficiency of plant production by irrigation and fertilizer placement will mean great demands even on soil sources. Particular attention must be paid to magnesium, sulfur, and the trace elements.

The marked increase in the nutrient content of young wheat plants brought about by irrigation may point to a noteworthy possibility to improve the quality of forage from pasture and ley. 


\title{
$S u m$ m a r $y$
}

In the dry summer 1969 the effect of irrigation and supply of available nitrogen on the production of dry matter and on the $\mathrm{N}, \mathrm{P}, \mathrm{K}, \mathrm{Mg}$, and Ca content of the aerial parts of spring wheat was studied on the basis of samples collected at various stages of development from a field trial.

Shoots collected from the irrigated plots (30 mm water on June 9 and $30 \mathrm{~mm}$ water on June 17) in the middle and at the end of June had a higher content of all the nutrients studied than those from the nonirrigated plots although at the latter date also the dry matter yield was markedly increased by irrigation. Later, the larger production of dry matter on the irrigated plots decreased this difference and resulted in equal or even somewhat lower contens of $\mathrm{N}, \mathrm{P}, \mathrm{K}, \mathrm{Mg}$, and $\mathrm{Ca}$ in the ears and straw, and also in the grains.

An improvement in the supply of available nitrogen tended to increase the dry matter yield and the content of $\mathrm{K}, \mathrm{Mg}$, and $\mathrm{Ca}$ in the vegetative parts of the plant; the $\mathrm{N}$ content was increased also in the ears and grains.

The positive interaction of water and nitrogen supply was distinct in the production of dry matter and in the uptake of nutrients. The high grain yields produced by irrigation and good or very good nitrogen supply were attributed, at least partly, to the more intensive uptake of nutrients during the period of vigorous growth in June.

It was emphasized that the improvement of the efficiency of plant production by irrigation and placement of fertilizers may result in an impoverishment of the soil of other nutrients.

\section{REFERENCES}

KaIlA, A. \& Elonen, P. 1970. Influence of irrigation and placement of nitrogen fertilizer on the uptake of nitrogen by spring wheat. J. Sci. Agric. Soc. Finland 42: 123-130.

KäHÄRI, J. \& ELONEN, P. 1969. Effect of placement of fertilizer and sprinkler irrigation on the development of spring cereals on the basis of root investigations. Ibid. 41: 89-104.

\section{SELOSTUS:}

\section{SADETUKSEN JA KÄYTTÖKELPOISEN TYPEN SAANNIN VAIKUTUS KEVÄTVEHNÄN KASVUUN JA RAVINTEIDEN PITOISUUTEEN}

\author{
Armi Kaila ja PaAvo Elonen
}

Yliopiston maanviljelyskemian laitos, Viikki

Yhteistyössä Maatalouskoneiden tutkimuslaitoksen kanssa kesällä 1969 Espoon Pakankylään järjestetystä sadetuksen ja eri typpilannoitteiden sijoituksen vaikutusta selvittävästä kenttäkokeesta kerättiin kasvukauden aikana näytteitä kevätvehnän maanpällisistä osista sadettamattomilta ja kesäkuussa kahtena eränä yhteensä $60 \mathrm{~mm}$ kasteluvettä saaneilta koeruuduilta. Typpilannoituksen tehokkuuden mukaan näytteet jaettiin edustamaan hyvin heikon, heikon, hyvän ja erittäin hyvän typensaannin asteita.

Sadetus oli lisännyt merkitsevästi vehnän typen, fosforin, kaliumin, magnesiumin ja kalsiumin pitoisuutta kesäkuun puolivälissä ja lopussa otetuissa näytteissä, vaikka jälkimmäisissä näytteissä myös kuiva- 
ainesato oli kasvanut sadetuksen vaikutuksesta. Myöhemmin sadetus lisäsi kuiva-ainesatoa siinä määrin, että erot vastaavien sadetettujen ja sadettamattomien koejäsenten näytteiden ravinteiden pitoisuuksissa pienenivät ja jopa muuttuivat päinvastaisiksi.

Typen saannin paraneminen lisäsi kuiva-ainesatoa kaikilla näytteen-ottokerroilla ja nosti vegetatiivisen aineksen kaliumin, magnesiumin ja kalsiumin pitoisuutta; typenpitoisuus nousi myös tähkissä ja jyvissä.

Vedellä ja typellä oli selvä positiivinen yhteisvaikutus kuiva-aineen tuottoon ja ravinteiden ottoon. Sadetuksella ja hyvällä typpiravitsemuksella saatujen jyväsatojen suuruus perustui ainakin osaksi siihen, että näiden koejäsenten kasveissa oli runsaasti elintoiminnoille tärkeitä ravinteita juuri voimakkaan kehityksen aikana kesäkuussa.

Tulosten perusteella tähdennettiin, että tehostettaessa maan tuottokykyä sadetuksella ja voimakkaalla sijoituslannoituksella on varottava, ettei maa pääse köyhtymään muista ravinteista. 